\title{
A ÉTICA DA ESTÉTICA EM LIMA BARRETO: ANÁLISE DA CRÔNICA “A INSTRUÇÃO PÚBLICA” PELA SOCIOLOGIA COMPREENSIVA
}

\author{
AESTHETICS OF ETHICS IN LIMA BARRETO: THE \\ ANALYSIS OF THE CHRONICLE "PUBLIC INSTRUCTION" \\ THROUGH THE COMPREHENSIVE SOCIOLOGY
}

Marília Köenig $^{1}$ Senac - SC

\begin{abstract}
RESUMO
O presente trabalho objetiva destacar a ética da estética da obra do escritor carioca Lima Barreto (1890-1922), abordando, de seu legado, questões que parecem transcender a modernidade. O relato do cotidiano (ou da vida sem qualidade, no entender de Maffesoli, (1995; 2001; 2007; 2010) e o delineamento do imaginário social da nova República estariam marcados na Literatura militante do autor. O objetivo geral deste trabalho é apontar como a ética da estética de Lima Barreto, pode classificá-lo como escritor transcendente à modernidade ou transmoderno. Para investigar a hipótese, foi analisada a crônica "A instrução pública" da coletânea Vida urbana (1956). Já como critérios para a análise utilizaram-se os quatro pressupostos da Sociologia Compreensiva (MAFFESOLI, 2010). Este foi, portanto, o método adotado, para o qual o que interessa são os fenômenos sociais como estes se apresentam, e não como deveriam ser (MORAES, 2012). Por meio da análise, confirmou-se a hipótese fundamental do trabalho. Lima Barreto pode ser considerado um escritor transmoderno, visto que suas crônicas são marcadas por diversos dos traços transcendentes à Literatura moderna e este se revela, pelas lentes da Sociologia Compreensiva, um ávido pesquisador de imaginários (SILVA, 2006).
\end{abstract}

PALAVRAS-CHAVE: Lima Barreto. Ética da estética. Modernidade. Sociologia Compreensiva

\begin{abstract}
The present work attempts to emphasize the aesthetics' ethics in the work of the carioca writer Lima Barreto (1890-1922), broaching from his legacy questions that seem transcend the modernity. The report of daily life (or of life without quality, in the opinion of Maffesoli (1995; $2001 ; 2007$; 2010) - and the delineation of the social imaginary on the new Republic would be marked into the militant Literature of the author. The general purpose of this work is to point how the aesthetics' ethics of Lima Barreto, can classify him as a writer who transcends the modernity or as a transmodern. To investigate the hypothesis, the chronicle "A instrução pública" from the collectanea Vida urbana (1956) was analyzed. The criteria for the analysis were the four assumptions of Comprehensive Sociology (MAFFESOLI, 2010). This was therefore the method used, for which what interest are the social phenomena as these present themselves, and not as they should be (MORAES, 2012). Through the analysis, it was confirmed the fundamental hypothesis of the work. Lima Barreto can be considered a transmodern writer, since his chronicles are marked by several traces, which transcend the modern Literature and this one reveals itself, by the lenses of Comprehensive Sociology, an avid researcher of imaginaries (SILVA, 2006).
\end{abstract}

${ }^{1}$ Doutora em Ciências da Linguagem. E-mail: maiam 78@hotmail.com 
KEYWORDS: Lima Barreto. Aesthetics'ethics. Modernity. Comprehensive sociology.

\section{Literatura e Imaginário}

Sendo a Literatura uma das materialidades do imaginário e objeto de estudo deste trabalho, cabe destacar o que Legros (et al, 2007), propõe. Ele enfatiza os estudos de Tacussel a respeito de $A$ comédia humana, de Honoré de Balzac, pontuando que esta não somente compõe um retrato da realidade social do capitalismo industrial, a qual é amplamente modificada pelo processo de industrialização imposto pelo Capitalismo. Signo, aliás, fortemente presente em Lima Barreto, escritor analisado no escopo deste trabalho.

Turchi (2003), em seus estudos sobre a Antropologia do imaginário na Literatura em obras de Guimarães Rosa, Carlos Drummond de Andrade e Antonio José de Moura, destaca, na narrativa, o arquétipo do herói, sua elevação e o aviltamento do algoz. Aquele quanto mais é "esprimido (sic) e aniquilado, tanto mais se eleva; quem decai e fica em situação aviltante é o algoz, aquele que aparenta uma posição privilegiada." (p. 226)

Entram em cena, ainda, os arquétipos do mártir e do guerreiro, sendo estes, de acordo com a pesquisadora, duas faces de uma mesma moeda (TURCHI, 2003, p. 226). Enquanto aquele renuncia, cabe a este afirmar "sua verdade interior, sua fé no 'querer'; o ato volitivo se impõe e supera o martírio, ditando normas para a ação" (TURCHI, 2003, p. 226). Turchi salienta, ainda, que cabe aos guerreiros ser "duros e realistas para exterminar os dragões" (TURCHI, 2003, p. 26). Os dragões, nesse caso, poderiam ser os estritos padrões literários da época, a ideia que se tinha de modernizar o Rio de Janeiro "pelo alto", os desmandos das instituições oficiais. Ideia à qual o "guerreiro e mártir" Lima Barreto pode atender, em atenção à terminologia arquetípica ora citada pela autora. Resende (1989) no artigo Lima Barreto e a República, lembra o crítico posicionamento de Lima Barreto com relação à República, expressados no livro Triste fim de Policarpo Quaresma e, de modo geral, em toda sua atividade jornalística e literária, em especial na coletânea de crônicas Vida urbana, da qual se destacou a crônica aqui analisada. "É bastante conhecido o posicionamento crítico de Lima Barreto como romancista e contista do início do século em relação à República implantada no Brasil. Em especial a severidade dos primeiros tempos" (RESENDE, 1989, p. 89).

Os gêneros literários podem ser colocados sob a égide de três mitos, os quais são simbolizados pela espada ("Prometeu e o desafio aos céus"), a roda (Sísifo, em seu eterno recomeço na direção do cume da montanha) e a taça (Hermes e a eterna metamorfose para libertar a alma presa na matéria). Turchi (2003) também reitera, em torno da contemporaneidade, que o retorno de Hermes não significa promover a exclusão do racional, nem tampouco sua prevalência. Com ele, o indivíduo enfrenta o despotismo da razão, assegurando a equivalência entre o imaginário e a realidade.

A Literatura constituiu um poderoso vetor de ideias e imagens e, portanto, grande fonte de realimentação do imaginário social, sendo este um reservatório-motor (SILVA, 2006). E, nesse sentido, talvez por haver destoado dos cânones médios (ao optar até mesmo por um estilo mais coloquial de escrever, desafiando os padrões canônicos), Lima Barreto foi valorizado cinquenta anos depois de sua morte, haja vista a forte rejeição sofrida por ele na cena literária de seus dias.

Conforme Prado (MEC, 2005, p. 4), "é interessante como a literatura, mesmo fora de moda, em certo momento, é descoberta; ela fica pairando naquele horizonte, sempre pronta para um alarme da nação e da coletividade, em termos de consciência e de libertação".

Lima Barreto, pelas razões já citadas, mostra-se, enfatiza Prado, um escritor peculiar; sua identificação com o anarquismo e o antipaulistanismo (MEC, 2005) faz dele um crítico da modernidade. Um antimoderno não no sentido de criticar o movimento modernista, mas a ditadura das máquinas promovida pela modernidade. 
Cabe aqui destacar os conceitos bakhtinianos de dialogismo e polifonia (1992). Bakhtin destaca que quando recebemos uma enunciação significativa, esta nos propõe uma réplica: concordância, apreciação, ação, etc. Dialogismo, para Bakhtin, é o diálogo travado entre textos e linguagens. Define-se como a relação necessária entre um enunciado e outros, os quais são, segundo Stam (1992), conceitos mutuamente conscientes, refletindo-se também de forma recíproca.

Pela amplitude do significado do termo polifonia (a discussão de vozes por vezes polêmicas em um discurso) em relação ao de dialogismo, pode-se afirmar que esse conceito corresponde à interdiscursividade, ao confronto de vozes polêmicas, entendendo-se textos como produtos de discursos. Assim, compreender, portanto, não equivale a reconhecer a forma linguística, nem o processo de identificação; o que realmente é importante é a interação dos significados das palavras e seu conteúdo ideológico.

Assim, conforme Bakhtin, a luta do artista/autor por uma imagem da personagem é, permanentemente, uma luta dele consigo mesmo (KÖENIG, 2005). Em Lima Barreto, "o autorcriador nos ajuda a compreender o autor-pessoa, e já depois, suas declarações sobre a obra ganharão significado elucidativo e complementar [...]" (STAM, 1992, p. 6).

$\mathrm{O}$ autor, aqui,

é a única energia ativa e formadora, dada não na consciência psicologicamente agregativa, mas em um produto cultural de significação estável” [...] reina até hoje pleno caos na estatística da criação verbal e particularmente na história da Literatura. A cada passo, esbarramos na confusão de pontos de vista diferentes, [...] de princípios vários de avaliação (STAM, 1992, p. 6).

Faraco (2009) destaca a concepção permanentemente dialógica que Bakhtin atribui à existência, posicionando-se contra qualquer tentativa ou tendência de monologizar a vida social. Nesse contexto, para Bakhtin, "uma atitude monológica ou um modelo monológico de mundo é autocentrado e insensível às respostas do outro, não as espera e não reconhece nelas nenhuma força decisiva. Pretende ser a última palavra" (STAM, 1992, p. 76). Questão esta que vai ao encontro do princípio da negação da referência única trabalhado por Maffesoli na Sociologia Compreensiva, método basilar de análise utilizado neste trabalho.

Firma-se, ainda na terminologia bakhtiniana uma confluência baseada na polifonia (BAKHTIN, 1992), na qual, via narrativa, é possível "ouvir" as diversas vozes sociais (FARACO, 2009) que perpassam o discurso de Lima Barreto, o qual também se utilizou da carnavalização, conceito bakhtiniano que consiste na ideia de seu criador, o qual buscou

sonhar com um mundo polifônico, um mundo radicalmente democrático, pluralista, de vozes equipolentes, em que, dizendo de modo simples, nenhum ser humano é reificado; nenhuma consciência é convertida em objeto de outra; nenhuma voz social se impõe como última e definitiva palavra. Um mundo em que qualquer gesto centrípeto ${ }^{2}$ será logo corroído pelas forças vivas do riso, da carnavalização, da polêmica, da paródia, da ironia (FARACO, 2009, p. 79).

\footnotetext{
${ }^{2}$ Em direção ao centro, da visão dominante, do status quo.
} 
É dele a voz que denuncia a desigualdade, critica a miséria e denota a violência urbana (não somente física, como a simbólica, na forma de segregação, a qual ele mesmo é relegado pela condição de escritor negro, pobre e tido como marginal), em todos os seus matizes. Aspecto este, a marginalização profissional de Lima Barreto, aliás, que Sérgio Miceli vai enfatizar em Intelectuais à Brasileira (2001).

Ele destaca que:

\begin{abstract}
Os estigmas corporais (no caso de Lima, ser negro), tendem a reforçar as disposições ('recusa' das carreiras mais gratificantes, interiorização de qualidades como a 'sensibilidade', adquiridas ao longo do processo de relegação mediante o qual os 'parentes pobres' transmitem a seus filhos todas as modalidades de handicaps ligados à sua posição social em falso (MICELI, 2001, p. 24).
\end{abstract}

Ao deixar o curso de Engenharia da Escola Politécnica, na qual se preparava para a carreira "dominante masculina" (na terminologia utilizada por Miceli), Lima Barreto desiste do "projeto de seu pai em transformá-lo em um 'júnior da classe dominante". Tal atitude vai produzir, no literato, um movimento de dupla exclusão: do rol dos acadêmicos da época e de seu próprio universo familiar. Esse movimento estará subjacente a todo seu legado, na forma de ironia e acidez ao descrever o cotidiano.

O princípio subjacente à experiência social de Lima Barreto (bem como às tomadas de posição estéticas e políticas que dela resultam) reside na convergência de dois movimentos opostos, a saber, a familiarização com o universo da classe dirigente mediante a educação singular que recebeu por intermédio de seu padrinho [...] e, de outro lado, a permanência do vínculo com sua classe de origem (MICELI, 2001, p. 35).

Essa dupla experiência de Lima Barreto apropriar-se de modos de pensar e sentir diversos a de seu meio natural permitiu ao literato carioca, conforme Miceli (2001), assumir "um ponto de vista objetivo acerca do mundo social a partir de sua primeira experiência nesse mundo". Lima Barreto foi um observador capaz de emitir sobre o cenário moderno que se configurava no Rio de Janeiro de seus dias um juízo extremamente abrangente ao retratar, via Literatura, e mais particularmente via crônica, o drama ao qual o processo de urbanização da então capital nacional relegara inúmeras pessoas. Nesse olhar, que retrata as agruras sociais de um sem número de moradores das periferias cariocas percebe-se certa consonância com a noção de socialidade da qual Maffesoli vai falar.

A Literatura engajada é o modo pelo qual Lima Barreto manifesta essa socialidade, por meio de uma escrita comprometida com aqueles que ele vai retratar em sua obra: os desvalidos, que, com Lima Barreto, ganham espaço no cenário da Literatura da Belle époque. A retomada de Lima Barreto, na década de 1970, na qual o conceito de pós-modernidade está começando a eclodir nas Ciências Sociais, não é por acaso. A socialidade está presente em sua obra que denuncia as desigualdades já tão gritantes na então capital federal. Percebe-se em seu texto, um sentir em comum, um movimento de partilha com os desvalidos, ou seja, ao se colocar na posição de quem aponta falhas, Lima Barreto o faz como membro de uma sociedade que exclui ao se modernizar. Coloca-se no papel de um porta-voz, ao criticar o sistema em que está inserido. Especialmente em suas crônicas essa característica fica bastante clara. Em Vida urbana, Lima Barreto defende as mulheres, critica as obras feitas "pelo alto" no Rio de Janeiro e expressa suas impressões sobre a religião e outras temáticas.

Santos, no artigo Lima Barreto: muito além dos cânones (2011, p. 2), destaca a contribuição de Lima Barreto para as letras nacionais, muito embora ele tenha sido tão rechaçado em seus dias. 
Ele foi um moderno do seu tempo... para além dos cânones... Ele encontrava em sua experiência marginal, em sua sensibilidade de escritor e, não menos importante, nas ruas do Rio de Janeiro, uma forma de expor o momento social, cultural, político e econômico pelo qual passava o Brasil. Era um momento de passagem, uma transição, que anos depois seria pensado, também, a partir de suas obras. Sua vida, marcada por sentimentos de profunda solidão e de exclusão, foi matéria prima para seus escritos, não obstante o literato tenha extrapolado estes sentimentos para dar forma a uma forte obra literária.

O texto de Lima Barreto é abrangente e voltado a retratar a socialidade brasileira, ao cotidiano, face à modernização da cidade e da agudização das desigualdades sociais, vê-se que muitas das questões que ele evoca entram em cena, nas Ciências Sociais, a partir das décadas de 60 e 70 do século passado. Época na qual, ressalta Prado em entrevista para o documentário Mestres da Literatura - Lima Barreto (MEC, 2005), talvez não por acaso, a obra de Lima Barreto ganhe espaço no cenário da Literatura nacional. Daí a hipótese em conectar/assemelhar o legado barretiano aos pressupostos da Sociologia compreensiva, a qual tem, como horizonte, a pósmodernidade ou modernidade tardia.

Schwarcz em Lima Barreto: triste visionário (2017, p. 10) destaca a militância e a recusa ao oficial de Lima em torno do direito dos negros. O que, na visão da autora deste artigo, o qualifica como promotor do estar-junto daqueles sobre os quais escrevia, de um sentir em conjunto (afrodescendente por origem, opção e forma literária) conforme pontua Maffesoli.

\footnotetext{
Afrodescendente por origem, opção e forma literária, Lima Barreto combateu todas as formas de racismo, aqui e nos Estados Unidos - país que costumava hostilizar em seus escritos, pois julgava que por lá seus "irmãos de cor" eram tratados muito mal —, e desenhou seus personagens com particular ternura. Eles eram diferentes daqueles que o público estava habituado a encontrar nos romances que faziam sucesso então. Suas religiões híbridas destoavam do catolicismo oficial e imperante; os protagonistas variavam nos tons expressos na cor da pele, e moravam em locais mais distantes do centro da cidade, que ressoavam um passado africano. Uma África afetiva e pessoal, da "margem de cá”, um continente imaginado e recriado no país.
}

Era tanto um estranho no ninho no seio de sua família, diante dos padecimentos de um pai doente mental e das inúmeras dificuldades de ordem material que enfrentou, bem como era tido como escritor marginal. "Lima Barreto era desse jeito, cheio de ironias, deboches, contradições e acertos, ideias fortes e recorrentes, idiossincrasias, angústias, sofrimentos" (SCHWARCZ, 2017, p. 11). O que fica evidente em sua obra é, justamente, esse duplo sentimento de inadequação.

\section{A comunidade brasileira imaginada em Lima Barreto}

Em Comunidades Imaginadas (2005), Benedict Anderson menciona alguns conceitos fundantes às questões 'ora estudadas. Enfatiza, para tanto, as transformações operadas nos movimentos marxistas, tendendo, estes, a se tornarem nacionalistas. Refuta, para tanto, a ideia de que a era do nacionalismo está chegando ao fim. E ressalta também, por assim dizer, ser o fator nacional o mais universalmente legitimado entre os valores da vida política da contemporaneidade.

É, por assim dizer, uma definição em aberto, sendo o nacionalismo considerado uma "anomalia". Anderson pontua, desse modo, que tanto as teorias marxistas quanto as liberais desgastaram-se "numa tentativa ptolomaica de salvar os fenômenos" referentes à questão do nacional. Frisa, ainda, preferir o termo nacionalidade, dada a "multiplicidade de significados desse termo, sendo que o fator nacional e o nacionalismo são artefatos culturais 'de um tipo especial"' (p. 23). 
Desse modo, o deslocamento do sujeito inerente à pós-modernidade, não obstante sua perspectiva perturbadora, manifesta características positivas. Concomitantemente à dissolução das identidades estáveis do passado, abre-se campo a novas articulações: a criação de novas identificações, produzindo novos sujeitos (HALL, 2006).

Um aspecto que é também interessante destacar é aquele que diz que, de forma geral, todos podem, devem ter ou terão uma nacionalidade, sendo esta uma condição inerente e indispensável ao espírito gregário do ser humano.

Ressalta, para tanto, paradoxos referentes ao conceito de nação: a modernidade objetiva das nações aos olhos do historiador versus a sua antiguidade subjetiva, no sentido da tradição da qual Hall (2006) fala e Maffesoli $(2001 ; 2007)$ também aborda, quando enfoca os arcaísmos que constituem a pós-modernidade ou modernidade tardia.

Nesse ponto, a visão "oficial" da nacionalidade como um conceito de natureza sociocultural foi forjado em muitas nações, conforme Anderson (2005, p. 126), desenvolvendo-se posteriormente "e em reacção (sic) aos movimentos nacionais populares que proliferavam na Europa desde os anos 20 do século XIX".

Esse nacionalismo "oficial", portanto, estaria em contraposição ao conjunto tácito e informal de fatores que fazem de uma coletividade uma nação, conforme Anderson (2005) pontua. Essa relação tácita, intuitiva e extraoficial corresponde ao sentido da socialidade destacado por Maffesoli (1995).

Anderson (2005) reforça que, em um sentido antropológico, a nação seria uma "comunidade política imaginada" (já que não há qualquer indicativo material que denote isso) e que "é imaginada ao mesmo tempo como intrinsecamente limitada e soberana" (ANDERSON, 2005 , p. 25).

Nesse contexto, a Literatura foi uma das formas mais vigorosas para instituir, no Brasil, a ideia de uma nação; um grupo o qual, ainda que em tão vasto e heterogêneo território, compõe um mesmo coletivo. No que tange ao papel da Literatura brasileira na formação da ideia da nação. A nacionalidade, aqui, ficava "por conta do 'sentimento íntimo', exigindo-se da Literatura, por conseqüência (sic), articulação estética” (WEBER, 1997, p. 172).

De forma geral, já a partir da introdução, Anderson trabalha os conceitos de nacionalismo, nacionalidade (o qual ele prefere para definir essa comunidade imaginada) e nação como um postulado imaginário. As comunidades, assim, seriam distinguidas pelo modo como são imaginadas. Não há, por isso, um caráter falso/genuíno que a elas se possa atribuir.

Portanto, a nação é imaginada como uma comunidade porque, independentemente da desigualdade e da exploração reais que possam prevalecer em cada uma das nações, é sempre concebida como uma agremiação horizontal e profunda [...] (ANDERSON, 2005, p. 27).

Nesse sentido, a escolha da língua oficial era, acima de tudo, "uma questão de herança inconsciente ou de maior conveniência" (ANDERSON, 2005, p. 27). Assim como o Português castiço difundido via norma culta parnasiana, à qual Lima se opôs veementemente fazendo uso, em sua escrita, de uma variedade linguística mais coloquial e próxima à fala, conforme se aborda posteriormente no contexto deste trabalho.

Tudo depende, então, da forma como as comunidades são imaginadas. Por assim dizer, então, aqui se inserem a nação pensada de forma satírica por Lima Barreto em Os Bruqundangas e as comunidades - literária e jornalística - descritas de modo ácido e contundente em Recordacões do escrivão Isaías Caminha e na crônica selecionadas da coletânea a ser analisada neste trabalho, Vida urbana. Destaque para o compartilhamento dos significados, dos sentidos que, em sociedade, atingem um sem-número de pessoas por meio do lado mais sórdido da modernização, a urbanização voraz e sem planejamento.

Sobre tal aspecto, Ribeiro (2000) discorre. E aqui, a ética da estética de Lima Barreto será primordial para se formar, ainda que muito posteriormente à morte do literato carioca, o 
imaginário da República recém-instaurada no Brasil. "Compartilhar significados constitui précondição da cultura e da sociedade. Em sentido amplo, todas as comunidades são imaginárias. Os indivíduos só podem pensar em si mesmos enquanto membros de uma coletividade via meios simbólicos. Símbolos e signos são entidades sociais que invadem os indivíduos" (RIBEIRO, 2000, p. 1).

Contudo, a esse movimento há sempre os focos de resistência. Pode-se dizer que, embora a Literatura empreendida por Lima Barreto retratasse com fidelidade filhos da nação desvalidos pela proclamação da República, no Brasil, não era o retrato que se desejava, em nível mais amplo, divulgar sobre o país.

Por intermédio da Literatura, deu-se origem ao que Hall (2006, p. 52) denomina "narrativa da nação", a qual visa gerar, em pessoas de diferentes origens, raças, credos e culturas, um sentimento de pertença e de unidade. A narrativa da nação é o discurso constantemente contado e recontado "nas histórias e nas literaturas nacionais, na mídia e na cultura popular". Estas "simbolizam ou representam as experiências partilhadas, as perdas, os triunfos e os desastres que dão sentido à nação".

Ainda em torno das questões identitárias, para Ribeiro (2000, p. 9), "quando o que se discute são identidades nacionais, formas de representação que buscam o plano da homogeneidade, dificilmente se aceita a fragmentação de identidade como uma possibilidade de explorar, a partir de um ponto de vista específico, a experiência da diversidade cultural". Tal fator se pode perceber na prosa de Lima Barreto. Por meio da diversidade, da desigualdade social a qual alude, talvez ele tenha trilhado esse percurso: o de representar, pelo retrato da fragmentação, a nação brasileira de seus dias.

E é justamente esse cenário que a crônica de Lima Barreto, conforme se vai vislumbrar na análise empreendida neste trabalho, vai denunciar. Nele, o debate está focado na face obscura da modernidade brasileira, seguindo o caminho contrário dos discursos oficiais da Belle époque (MELO, 2010).

Nesse contexto, lembra o autor, é nítido "o compromisso assumido pelos bacharéis polemistas da república das letras brasileira com as principais correntes do pensamento filosófico e científico ligadas ao liberalismo" (MELO, 2010, p. 19).

Ortiz (1991) apregoa como tais fundamentos científicos, já em declínio na Europa, chegaram às terras tupiniquins, com o objetivo de estruturar o processo de construção da identidade nacional que coadunasse com a modernidade. Para o contexto do presente artigo, contudo, há algo ainda mais interessante levantado pelo sociólogo e também pontuado por Melo (2010, p. 19). Ocorre, inclusive, durante o predomínio do Romantismo, "um verdadeiro silenciamento de debates ligados à condição dos africanos e dos afro-brasileiros nos meios intelectualizados da época, até o advento da Abolição".

Voz dissonante que Lima Barreto, principalmente, por sua "dupla exclusão", conforme os termos de Resende (in SCHWARZ, 1983) e Miceli (2001), vai fazer ecoar no contexto literário da Belle époque por meio de sua prosa militante.

No contexto pós-moderno (e pós-colonial) em se vive, de acordo com Homi Bhabha (1998), se está em combate a essa visão hegemônica da nacionalidade. Busca-se, em contraposição, a história e a vivência dos povos, em favor de uma visão mais plural e que transmita de fato a heterogeneidade e hibridismo que formam as sociedades.

Na concepção do autor, então,

as perspectivas pós-coloniais emergem do testemunho colonial dos países do Terceiro Mundo e dos discursos das "minorias" dentro das divisões geopolíticas de Leste e Oeste, Norte e Sul. Elas intervêm naqueles discursos ideológicos da modernidade que tentam dar uma "normalidade" hegemônica ao desenvolvimento irregular e as histórias 
diferenciadas de nações, raças, comunidades, povos. Elas formulam suas revisões críticas em torno de questões de diferença cultural, autoridade social e discriminação política a fim de revelar os momentos antagônicos e ambivalentes no interior das "racionalizações" da modernidade (BHABHA, 1998, p. 99).

Portanto, de forma diversa (para não dizer avessa) à Literatura ufanista de seu tempo, Lima Barreto compôs uma ideia de nação mais conectada ao cotidiano, mais realista (até por seu viés jornalístico, no fazer literário) e distanciada dos deleites próprios à Literatura do "sorriso da sociedade".

\section{A ética da estética em Lima Barreto: transcendência à modernidade}

A ética da estética a qual Maffesoli (2007) alude refere-se à expressão, também por meio da arte, do espírito coletivo que marca a pós-modernidade.

A ética, no entendimento maffesoliano, funciona como um "julgamento da existência", o que em muito ultrapassa um "julgamento de valor" (2005, p. 11). Tal sensibilidade teórica dedica-se à diminuição da dicotomia imposta na modernidade entre a razão e o imaginário (ou entre a razão e o sensível). Essa ética estaria em oposição a uma moral de valores estritos (marca da modernidade), em favor da socialidade aberta e plural, na qual a diversidade de valores e modos de vida dos indivíduos é considerada, estilizada e compartilhada.

Em No fundo das aparências (2005), Maffesoli destaca a estetização da existência, "dar à estética um sentido pleno (p. 12); a necessidade de tornar emocional o laço social". O que, pela hipótese ora traçada, já se percebe nas crônicas barretianas. Para o teórico, esse é o melhor meio “de denominar o 'consenso' [...] dos sentimentos partilhados ou das sensações exacerbadas" para atingir a socialidade.

A ética estaria aqui posta como algo particular, agregador, em muitos momentos, efêmero, elaborando-se a partir de um território dado, "seja ele real ou simbólico." (MAFFESOLI, 2005, p. 16), como elemento fortalecedor de determinado grupo. A separação entre ética e estética se deu durante muito tempo, sendo recorrente na modernidade, época na qual a racionalidade e os padrões sobrepujaram a sensibilidade e a subjetividade.

O teórico propõe uma identificação por meio do conceito aglutinador de ética da estética. O que se vê em Lima Barreto quando, ao ler Vida urbana, supõe-se essa transcendência com relação à modernidade. Visão a qual, nessa perspectiva, já é possível vislumbrar no olhar de Lima Barreto sobre o cotidiano ao se propor ter sido ele um literato transcendente aos valores expostos e trabalhados na Literatura de seus dias sob um olhar abrangente, que leva em conta as diversas imposições sociais (MAFFESOLI, 2005), não em função de um otimismo "de privilegiado, mas considerando o sólido vitalismo social que, mesmo através das mais duras condições de vida, não deixa de se afirmar [...] (MAFFESOLI, 2005, p. 12).

Um modo de apreciar em conjunto, de modo consensual ("cum-sensualis"). Uma “"sensibilidade da razão, a saber, o que em todos os domínios: políticos, profissionais, morais, abala a razão por essas forças sensíveis que são as da vida privada ou pública. Observar que há uma sinergia cada vez mais pronunciada entre o pensamento e a sensibilidade" (MAFFESOLI, 2005, p. 12).

A ética está refletida na arte e no conhecimento produzidos na modernidade tardia (estética). Essa seria a ética da estética transcendente à fragmentação e à óptica racionalista da modernidade. Ética da socialidade na qual, para a hipótese trabalhada aqui, Lima Barreto está inserido. 
$\mathrm{Na}$ modernidade, portanto, a questão do estilo estava circunscrita ao domínio da arte, haja vista haver, nesse cenário, uma dissociação entre os diversos campos de atividade humana, estando a economia separada da ciência, a ciência separada da arte, a arte separada da religião, etc.

$\mathrm{Na}$ modernidade tardia tem-se uma interação entre os diferentes campos da vida social, no qual o estilo pode ser compreendido como "princípio de unidade". Isso, aliás, parece já estar presente em Lima Barreto. Pela ética de sua estética, Lima Barreto, no entendimento de Santos (2011, p. 6),

\footnotetext{
Poder-se-ia dizer, talvez ainda, que Lima Barreto é fora de época, ou um extemporâneo, se pensar-se em cânones; porém, ele consolidou algo que é difícil em se tratando de crítica: ele foi contemporâneo a si mesmo, ou seja, ele enxergou com lucidez (...) o momento pelo qual passavam a sociedade brasileira, a ciência médica e psiquiátrica, a cidade do Rio de Janeiro e as próprias questões literárias.
}

Como narrador do vivido, Lima Barreto já imprime às obras muito do cotidiano no qual vive. Até a variedade linguística por ele utilizada, marcada pela coloquialidade, parece dar conta do objetivo de transpor, via Literatura, a sua vivência. "Elabora-se um modo de ser (ethos) onde o que é experimentado com os outros será primordial" (MAFFESOLI, 2005, p. 12). É isso o que o autor francês designa por ética da estética.

\section{Procedimentos Metodológicos}

Para explicitar a constituição desse saber relativamente recente chamado Sociologia Compreensiva, Maffesoli desenvolveu quatro pressupostos fundamentais, os quais serão critérios de análise à crônica de Lima Barreto. São eles:

1. Crítica ao dualismo esquemático - (ou... ou), a qual foi cara ao Positivismo. $O$ pensamento racionalista, o qual foi base da modernidade, não é suficiente. É preciso haver integração entre razão e componentes da personalidade, resultando em uma conjunção entre a erudição (razão) e a paixão (sentimento e imaginação).

2. A “forma" - opondo-se à excessiva formalização e conteúdo. Para o teórico, "a forma permite a apreensão da imagem e de sua pregnância no corpo social" (MAFFESOLI, 2010, p. 49). Daí a importância de não haver uma forma única, de modo que a excessiva formalização não restrinja o significado.

3. Uma sensibilidade relativista - Esta é manifestada pelo relativismo metodológico que avança e "se consolida nos diversos campos da vida social" (MAFFESOLI, 2010, p. 38);

4. Um pensamento libertário - Esse pressuposto indica a necessidade do pesquisador inteirar-se com seu ambiente imediato. Opera em favor da "liberdade do olhar" (MAFFESOLI, 2010, p. 46), que permite trocas rompendo com a referência única. Lima Barreto fez isso contrariando, ao questionar e desafiar, os padrões ao transpor, ao texto literário, uma realidade diversa por meio de uma prosa ousada, em se tratando do contexto ao qual o presente trabalho alude.

Tais pressupostos darão origem à pesquisa estilística, que se interessa mais pelo "como se" do que pelo "por quê". Sugere-se constante intercâmbio entre a forma e a empatia. Tal metodologia, longe da noção de ensaísmo a ela atribuída por "mestres-escolas" (MAFFESOLI, 2010, p. 42), compreende uma estilização da existência.

Lima Barreto, de certo modo, dá destaque à dissolução do sujeito uno, desafiando os padrões positivistas ora vigentes, na Belle époque, reproduzindo, em suas obras, o indivíduo 
dissonante. Este se pode identificar no cotidiano da República recém-proclamada, na qual a modernização é um processo iminente.

Por isso, este trabalho se propõe a investigar a hipótese de o escritor carioca ter transcendido a modernidade, ao criticar, denunciar e até por propor uma visão alternativa à da Literatura de "deleite" de seus dias, não se projetando e

\begin{abstract}
porvires promissores, na realização de utópicas sociedades perfeitas ou outros paraísos, profanos ou religiosos. Quando a literatura ou a ficção surgem como elementos criadores, em qualquer domínio que seja, elas o mostram repletos de contradições [...] contradições que, de fato, asseguram a riqueza e a fecundidade do gênio em questão (MAFFESOLI, 2010, p. 66).
\end{abstract}

Por seu legado, Lima Barreto parece corroborar o princípio maffesoliano que diz que a verdade não existe em si mesma, mas somente adquire sentido em relação a um dado conjunto social. Nisso, ressalta o teórico francês, "consiste a perspectiva relativista que, no ato do conhecimento, se vê atraída, antes de mais nada, pela sociedade que lhe serve de suporte" (MAFFESOLI, 2010, p. 142).

Não se insiste, contudo, em se instituir o conhecimento comum que a Sociologia Compreensiva se ocupa em explorar, como "forma superior de conhecimento", mas como a mais elementar e verdadeiramente comum, por dar conta do dinamismo da vida cotidiana.

\title{
3.1 “A Instrução Pública”
}

$\mathrm{Na}$ crônica que segue, Lima Barreto vai denunciar, de modo irônico e contundente, o culto ao doutor e os preconceitos que este engendra. $O$ título, de acordo com o literato, na conjuntura em que vive, está acima da competência ou de qualquer outro atributo (intelectual ou físico) de um indivíduo. Ele denota isso no fragmento a seguir. Em virtude dessa reverência ao doutor, este, "e é ignorante, o é; mas, sabe, por ser doutor. Se é preto, o é, mas... é branco".

Aqui, talvez o próprio preconceito sofrido pelo literato, haja vista sua condição de mulato, esteja aqui expressada em relação dialógica com outras de suas obras (como Recordaçoes do escrivão Isaías Caminha e Clara dos Anjos).

Nestas, os protagonistas, negros, sofrem todos os tipos de agruras por sua raça e condição socioeconômica. Enfatiza que ele mesmo (quando passou pela Escola Politécnica), "escapou de ser um doutor". A ironia (pela queda dos preconceitos que Lima Barreto sugere a partir da obtenção do título doutoral) se mostra aqui de modo contundente (HASSAN, 1987).

\footnotetext{
No Brasil, o doutor (e olhem que eu escapei de ser doutor), é um flagelo, porque se transformou em nobreza e aos poucos foi açambarcando posições, fazendo criar coisas novas para eles, arrendando com o preconceito doutoral as atividades e as competências. [...] A tendência vai se firmando, de constituir- se, entre nós uma espécie de teocracia doutoral. Os costumes, o pouco respeito do povo, estão levando as coisas para isso (BARRETO, 2013, p. 26).
}

Lima, tido como "marginal das Letras" pelos "medalhões" da época, foi transcendente à modernidade, desenvolvendo, se comparado aos cânones, algo como uma antiliteratura. Em vez do deleite, a ironia ferina (marca das produções que criticam a modernidade). Traço que, de muitas formas, o aproxima de Machado de Assis, outro mulato das Letras nacionais. Machado, contudo, ironizou o sistema a partir de seu ingresso junto aos cânones, enquanto Lima Barreto o fez a partir de sua dupla exclusão (social e literária, em seus dias) (MICELI, 2001). 
Além disso, fim em evidência, a partir da crítica ao dualismo esquemático próprio à modernidade (MAFFESOLI, 2010), a rejeição, a angústia e a crescente desigualdade social trazida pelo processo de modernização "pelo alto" - estrutural em detrimento do social - sofrido pelo Rio por ocasião da eclosão do regime republicano e pela urbanização.

Percebem-se, ainda, os traços da descanonização, e, portanto, da expressão de um pensamento libertário - em favor da "liberdade do olhar" (MAFFESOLI, 2010, p. 46). O que representa um rompimento com a referência única representada pelos padrões e conteúdos abordados pela Literatura da Belle époque tupininquim. Transgride-se a ideia do conhecimento formal como única condição para ser valorizado, em sociedade (evidenciado pela crítica que Lima promove aos expoentes intelectuais da sociedade, os doutores). Há, ainda, a carnavalização (conceito bakhtiniano que indica, por meio da paródia, o evidenciar da óptica dos contrários). Esta, aqui, se expressa por meio da possibilidade da aplicação do adágio "rir para não chorar" diante do respeito tão somente a um simples título).

A crítica ao dualismo (ou ser doutor, ou não ser nada) é possível vislumbrar aqui, sendo a crítica a esse um dos princípios da Sociologia Compreensiva, a qual vê o cotidiano não como um conjunto de dicotomias (ou... ou), mas uma infinidade de possibilidades de caminhos, formas e temas a serem trabalhados.

Ainda na crônica, o orgulho e arrogância dos "bachareletes" motivados por boas colocações e casamentos polpudos são destacados:

As famílias, os pais, querem casar as filhas com os doutores; e, se estes não têm emprego, lá correm à Câmara, ao Senado, às secretarias, pedindo, e põem em jogo a influência dos parentes e aderentes. Então, o orçamento aparece com autorizações de reformas e o bacharelete está empregado, repimpado como diretor, cônsul, enviado extraordinário e diz para nós outros: "Eu venci” (BARRETO, 2013, p. 26).

Reforça-se, mais uma vez, que o culto ao doutor aparece em todas as esferas da sociedade carioca. A abordagem de Lima à questão guarda algo de semelhante ao tom irônico empregado por Machado de Assis em Teoria do Medalbão. Não obstante a dedicação e experiência de um profissional, se não tem um título, este "não é nada".

No que tangia aos meios de comunicação da época, a reverência doutoral era também disseminada.

Nem os jornais escapam a essa superstição. Antigamente, os autores eram conhecidos pelos seus simples nomes; agora, eles aparecem sempre citados com o seu título universitário. $\mathrm{Na}$ burocracia, a coisa é a mesma. Um empregado é mais competente do que outro, na matéria de montepio, porque aquele é engenheiro de minas e o outro não é nada (BARRETO, 2013, p. 26).

Finalmente, no trecho em que o escritor destaca a instrução secundária e como esta deveria ser (em vez de apenas a preparação de doutores ser fortalecida), surge, novamente, a busca por maior igualdade entre as classes e os gêneros.

A sensibilidade relativista (MAFFESOLI, 2010) é, aqui, o princípio observado. Uma escola secundária em que não haja exclusão por dentro (1996; 1998), a qual o sistema educacional da época promovia, em seus dias (e ainda promove, daí a atualidade dos temas abordados por Lima Barreto). "No que toca à instrução secundária, ainda poderia manter liceus, nos bairros, e, prover, de fato, a instrução secundária, no distrito, sem esquecer que o deve fazer também para as moças" (BARRETO, 2013, p. 26).

Muito embora fosse um opositor ao movimento feminista, sempre foi crítico contumaz aos abusos e à educação restritiva conferida à mulher e ao pobre, na sociedade. 
$\mathrm{Na}$ continuação à crônica, dois dias depois, Lima Barreto destaca que, em matéria de instrução, o governo "tanto imperial como republicano, tem sido madrasta a esse respeito" (BARRETO, 2013, p. 26). Novamente, aqui, ao criticar a instrução militar e a instituição de liceus como o Pedro II (onde estudou com membros da elite carioca), Lima reflete sobre o quanto seria importante que as mulheres fossem devidamente educadas, pela melhoria das gerações.

\begin{abstract}
Ambos, e, sobretudo, o Colégio Militar (e o Pedro II), custam os olhos da cara e o dinheiro gasto com eles dava para mais três ou quatro colégios de instrução secundária neste distrito. Acresce ainda que o governo sempre se esqueceu o dever de dar instrução secundária às moças: um esquecimento de lamentar, porquanto toda a gente sabe de que forma a influência de uma educação superior da mulher iria influir nas gerações (BARRETO, 2013, p. 26).
\end{abstract}

Sugere, portanto, a abertura desses colégios, ao modo dos educandários franceses, abarcando a todos. E, de acordo com o literato:

\begin{abstract}
Se há alguma coisa a fazer em instrução que não seja a de fabricar doutores, é extinguir. Todos os colégios militares e o Pedro II, criando por todo o Rio de Janeiro liceus, ao jeito dos franceses, para moças e rapazes, de forma que os favores do Estado alcancem todos. Os colégios militares são sobremodo um atentado ao nosso regime democrático; é preciso extingui-los e aproveitar os respectivos professores e material, na instrução da maioria. Pelo menos, a República devia fazer isso (BARRETO, 2013, p. 26)..
\end{abstract}

Lima Barreto, na presente crônica e em sua continuidade, busca por uma sensibilidade relativista, pelo ato de pôr em relação diferentes sujeitos (homens e mulheres, ricos e pobres) e contextos. O literato parece coadunar, pelas ideias que expressa, com essa sensibilidade "manifestada pelo relativismo metodológico que avança e se consolida nos diversos campos da vida social” (MAFFESOLI, 2010, p. 38).

Seu estilo compõe uma antiforma se comparado ao que caracterizava seus contemporâneos parnasianos. Por essa razão, cabe olhar a produção barretiana à luz da pesquisa estilística proposta por Maffesoli (2010) quando aborda a Sociologia Compreensiva. Longe da noção de ensaísmo da qual Lima Barreto foi acusado, a ele atribuída por "mestres-escolas" (MAFFESOLI, 2010, p. 42), sua forma de escrever compreende justamente uma estilização da existência, denotada, no escopo deste trabalho, em cada linha da crônica de Vida urbana aqui analisada.

Percebe-se, ainda, a crítica ao dualismo esquemático (ou... ou), que foi caro ao Positivismo (tão execrado pelo autor). Pela perspectiva da socialidade, que para Maffesoli é comunhão, conforme preconiza Motta no prefácio de $O$ conhecimento comum (2010, p. 12), e da necessidade de o artista estar conectado à vida cotidiana, fortalece-se outro viés: o do sentimento comunitário que, destacado por Maffesoli (1995) como uma volta aos arcaísmos da humanidade, à retribalização, ou seja, às origens, ao sentido de pertença e à necessidade do coletivo para se exercer o individual. O que aqui também se expressa.

Contudo, Lima faz isso sem o "otimismo fingido das ideologias estruturais" (MAFFESOLI, 2001, p. 31). Faz, de sua antinarrativa, um caminho para a resistência.

\title{
CONSIDERAÇÕES FINAIS
}

$\mathrm{Na}$ análise detalhada da crônica "A instrução pública", de Vida urbana, parece que o escritor brasileiro Lima Barreto percebe "a rica e densa concretude cotidiana", a qual, para 
Maffesoli (2001), "permanece alérgica ao positivismo esquemático" (MAFFESOLI, 2001, p. 31). Dá vez, ao "jogo duplo da resistência" (MAFFESOLI, 2001, p. 32). Neste, um indivíduo vivencia algo, mas veementemente não se identifica com aquele contexto, e pode, remetendo-se ao contexto deste trabalho, transcendê-lo.

Lima Barreto "mergulha na bacia semântica do outro e trilha seu próprio trajeto, na contramão das verdades de acostamento e das certezas de retrovisor" (SILVA, 2006, p. 75). No percurso teórico trabalhado, lembra o estudioso, o pesquisador do vivido torna-se parte do imaginário que trilha. É portador, vale reforçar, de uma sensibilidade relativista, sendo ela manifestada "pelo relativismo metodológico que avança e se consolida nos diversos campos da vida social" (MAFFESOLI, 2010, p. 38).

Ainda em torno das questões identitárias, para Ribeiro (2000, p. 9),

Quando o que se discute são identidades nacionais, formas de representação que buscam o plano da homogeneidade, dificilmente se aceita a fragmentação de identidade como uma possibilidade de explorar, a partir de um ponto de vista específico, a experiência da diversidade cultural.

Tal fragmentação, porém, já parece estar presente na prosa de Lima Barreto, o que, talvez, já o classifique como escritor transcendente ao moderno, corroborando a hipótese lançada aqui.

Isso posto, por meio da diversidade, da desigualdade social a qual Lima alude, talvez este tenha trilhado o caminho de representar (ou re-presentar), pelo retrato da fragmentação, a nação brasileira de seus dias.

Acerca da recusa ao padrão linguístico, aliás, Resende ressalta que

O academicismo recusado é também a recusa do distanciamento escritor-público, é a busca do elemento popular no autenticamente nacional [...] o antagonismo que Lima Barreto estabelece entre sua escrita e a "escrita coelho-netista" é correspondente ao antagonismo que cresce entre os bairros "aristocráticos", "civilizados", de "gente fina" e os subúrbios com sua pequena burguesia e operariado de costumes e cultura próprios (in SCHWARZ, 1983, p. 74).

A proximidade com os dramas e a identificação de Lima Barreto com as agruras da nação jamais enfocada pela Literatura "do sorriso" são aspectos determinantes da ética de sua estética, da razão de ser de seu estilo. Aquele que, até a atualidade, permanece atual.

A recusa ao oficial, aliás, é ponto-chave destacado por Maffesoli (2007) no que a artistas e intelectuais membros do que ele chama de douta ignorância, na pós-modernidade. Tal noção foi incluída aqui para falar da ética da estética de Lima Barreto. Esta se propõe a lançar um desafio aos padrões impostos a literatos e artistas de seus dias.

Nesse ínterim, observa Resende (in SCHWARZ, 1983, p. 74), o escritor fez o que Nélson Coutinho aponta como opção radical a um intelectual: vincular-se permanentemente às camadas populares. Foi essa a missão primordial de Lima Barreto.

Para Schwarcz (2017, p. 17), foi Lima Barreto "Um narrador que nunca se apaga diante do que acredita ser seu de direito. Ele que brigou, insurgiu-se, apoiou, vetou, enfim, fez todo o barulho que podia para que a República se tornasse uma res publica: o governo de todos para todos, e por todos", sendo esta sua relação com o sentir em comum.

A Sociologia Compreensiva deu conta dos objetivos como método adotado para análise. Para esta, o que interessa são os fenômenos sociais como estes se apresentam, e não como deveriam ser (MORAES, 2012). Lima Barreto pode ser considerado um escritor transcendente à modernidade ou transmoderno, visto que suas crônicas são marcadas por diversos dos traços 
transcendentes à Literatura moderna e este se revela, pelas lentes da Sociologia Compreensiva, um ávido pesquisador de imaginários (SILVA, 2006).

\section{REFERÊNCIAS BIBLIOGRÁFICAS}

ANDERSON, Benedict. Comunidades imaginadas: reflexões sobre a origem e expansão do nacionalismo. Edições 70: Lisboa, 2005.

BAKHTIN, Mikhail Mikhailovitch; VOLOCHINOV, V. N. Marxismo e filosofia da linguagem: problemas fundamentais do método sociológico na ciência da linguagem. 6. ed. São Paulo: HUCITEC, 1992.

BARBOSA, Francisco de Assis. A vida de Lima Barreto: 1881-1922. 6. ed. Rio de Janeiro: J. Olympio, 1981.

BARRETO, Lima. Os Bruzundangas. 3. ed. São Paulo: Ática, 2001.

Clara dos Anjos. Disponível em

http://www.dominiopublico.gov.br/pesquisa/DetalheObraForm.do?select action $=\&$ co obra $=2060$.

Acesso em 24 nov. 2012.

Recordações do escrivão Isaías Caminha. Disponível em <www.ufsc.br/nuppil >.

Acesso em 25 nov. 2012.

Vida urbana. Disponível em:

http://www.dominiopublico.gov.br/pesquisa/DetalheObraForm.do?select action $=\& c 0$ obra $=2$ 171. Acesso em 21 abr. 2014.

BHABHA, Homi. O local da cultura. Tradução de Myriam Ávila, Eliana Lourenço de Lima Reis e Gláucia Renate Gonçalves. Belo Horizonte: Editora da UFMG, 1998.

BOURDIEU, Pierre. A economia das trocas linguísticas: o que falar quer dizer. 2. ed. São Paulo: EDUSP, 1998.

. As regras da arte. São Paulo: Companhia das Letras, 1996.

FARACO, Carlos A. Linguagem \& Diálogo - as ideias linguísticas do círculo de Bakhtin. São Paulo: Parábola Editorial, 2009.

HALL, Stuart. A identidade cultural na pós-modernidade. Tradução de Tomaz Tadeu da Silva e Guaracira Lopes Louro. 11 ed. Rio de Janeiro: DP\&A, 2006.

HASSAN, Ihab. Fazer sentido: as atribulações do discurso pós-moderno. Revista Crítica de Ciências Sociais, n. 24, março de 1988, pp. 77-85.

KÖENIG, Marília. Por uma teoria não-oficial da comunicação: o Jornalismo como tema em Recordações do escrivão Isaías Caminha, de Lima Barreto (dissertação de Mestrado). Disponível em <http://busca.unisul.br/pdf/79421_Marilia.pdf >. Acesso em 10 nov. 2012. http://busca.unisul.br/pdf/79421_Marilia.pdf

. O spleen em Baudelaire e Lima Barreto: confluências e dissonâncias frente à modernidade (artigo). Florianópolis: 2008.

LEGROS, Patrick et al. Sociologia do imaginário. Tradução de Eduardo Portanova Barros. Porto Alegre: Sulina, 2014 - 2a ed. (Coleção Imaginário Cotidiano)

MAFFESOLI, Michel. A conquista do presente. Edição revista e atualizada. Tradução de Alípio de Souza Filho. Porto Alegre: Argos, 2001;

A contemplação do mundo. Tradução de Francisco Franke Satinelli. Porto Alegre: Artes e Ofícios, 1995.

. O conhecimento comum. Tradução de Aluizio R. Trinta. Coleção Imaginário Cotidiano.

Porto Alegre: Sulina, 2010;

O ritmo da vida: variações sobre o imaginário pós-moderno. Tradução de Clóvis

Marques. Rio de Janeiro: Record, 2007. 
MELO, Joachin. Uma outra face da Belle Époque carioca: o cotidiano nos subúrbios nas crônicas de Lima Barreto. Dissertação de Mestrado. Disponível em:

http://www.ufcg.edu.br/ historia/ppgh/images/dissertacoes defendidas/2008/joachin\%20melo.pdf. Acesso em 20 nov. 2014.

MICELI, Sérgio. Intelectuais à brasileira. São Paulo: Companhia das Letras, 2001

MINISTÉRIO DA EDUCAÇÃO - TV Escola. Lima Barreto: um grito brasileiro. Série Mestres da Literatura (documentário). Brasília, 2005.

Entrevista com Antonio Arnoni Prado. Escritores influenciados por Lima Barreto.

Disponível em<http://portal.mec.gov.br/seed/arquivos/pdf/revis\%C3\%83\%E2\%80\%A0o-

T.Lima-Arnoni.pdf>. Acesso em 20 mai. 2013.

MORAES, Heloisa Juncklaus Preis. A descoberta e a vivência do virtual: experiências infantis.

Florianópolis: DIOESC, 2012.

MOTA, Roberto. Introdução. In: MAFFESOLI, Michel. O conhecimento comum. Tradução de Aluizio R. Trinta. Coleção Imaginário Cotidiano. Porto Alegre: Sulina, 2010.

ORTIZ, Renato. Cultura e Modernidade: a França no século XIX. São Paulo. Editora Brasiliense, 1991.

PRADO, Antonio Arnoni. Entrevista. In: MINISTÉRIO DA EDUCAÇÃO - TV Escola. Lima Barreto: um grito brasileiro. Série Mestres da Literatura (documentário). Brasília, 2005.

RESENDE, Beatriz. Lima Barreto: a opção pela marginália. In: SCHWARZ, Roberto (org.). Os pobres na Literatura brasileira. Brasília: Brasiliense, 1983.

Dossiê 100 anos de República: Lima Barreto e a República. Disponível em: http://www.revistas.usp.br/revusp/article/view/65409. Acesso em 16 abr. 2018.

RIBEIRO, Gustavo Lins. Macunaíma: ser ou não ser, eis a questão. In: Cultura e política no mundo contemporâneo. Brasília: UnB, 2000.

SANTOS, Nádia M. W. Lima Barreto: muito além dos cânones. Disponível em: < http://cral.in2p3.fr/artelogie/IMG/article PDF/article a76.pdf >. Acesso em 18 abr. 2018.

SCHWARCZ, Lilia Moritz. Lima Barreto: triste visionário. 1 ed. São Paulo: Companhia das Letras, 2017. SILVA, Juremir Machado da. Tecnologias do imaginário. Porto Alegre: Sulina, 2006.

. O imaginário é uma realidade. Entrevista de M. Maffesoli. In: Revista FAMECOS - no 15 (quadrimestral). Porto Alegre, agosto de 2001.

STAM, Robert. Bakhtin: da teoria literária à cultura de massa. São Paulo: Ática, 1992.

TURCHI, Maria Zaira. Literatura e antropologia do imaginário. Brasília: Editora Universidade de Brasília, 2003.

WEBER, João Hernesto. A nação e o paraíso - a construção da nacionalidade na historiografia literária brasileira. Florianópolis: Editora da UFSC, 1997.

Recebido em 4/11/2017

Aceito em 3/4/2018 